\title{
Best Practices for Communicating about Outdoor Residential Water Conservation ${ }^{1}$
}

\author{
Jacqueline Aenlle and Laura A. Sanagorski Warner²
}

\section{Abstract}

Communication efforts can be made more effective by following a strategic communication plan. To guide a strategic communication effort, it is imperative to have purposeful messaging along with an understanding of your target audience and communication channel. This document presents a synthesis of literature highlighting best communication practices in regard to water conservation efforts.

\section{Summary of Best Communication Practices from Literature}

Based on current research (see Figure 1), effective water conservation messages will:

- Appeal to normative beliefs and include both gain-frames and social-value frames (Richetin et al., 2014; Rumble et al., 2017; Warner et al., 2015). Florida residents are more likely to adopt water conservation practices if they are seen as a social expectation (or something others will approve of) or are of personal value to their community (gain-frame and value-frame). Positive messaging that focuses on what audiences are "gaining" if they take action are generally better received than messaging that is focused on what audiences are "losing" if they do not take action. Examples of gain and loss frames that appeal to social norms are as follows.
- Gain: "By conserving water through good irrigation practices you will be seen as a role model in the fight to ensure that water is available for future generations" (Warner et al., 2015).

- Loss: "By wasting water through poor irrigation practices you will not be seen as a role model in the fight to ensure that water is available for future generations" (Warner et al., 2015).

- Utilize websites and print materials for communication efforts. Research has shown that the target audiences for these messages are most interested in seeking additional information from websites, print materials (i.e., facts sheets or brochures), or television (Lamm et al., 2016; Warner et al., 2017).

- To complement existing Extension and educational activities while still catering to this preference, ensure that during or after your programs (i.e., workshops) attendees are directed to a website for more information either verbally or by a handout with the link, and that workshop materials are presented in alternate formats (i.e., websites and print materials) whenever possible.

- Target specific key audiences. A target audience includes the individuals who are most likely to be interested in your service and information, as well as the individuals you are hoping to reach with your communication efforts. These key audiences may include but are not limited to:

1. This document is AEC703, one of a series of the Department of Agricultural Education and Communication, UF/IFAS Extension. Original publication date September 2020. Visit the EDIS website at https://edis.ifas.ufledu for the currently supported version of this publication.

2. Jacqueline Aenlle, graduate assistant, and Laura A. Sanagorski Warner, associate professor, Department of Agricultural Education and Communcation, UF/IFAS Extension, Gainesville, FL 32611.

The Institute of Food and Agricultural Sciences (IFAS) is an Equal Opportunity Institution authorized to provide research, educational information and other services

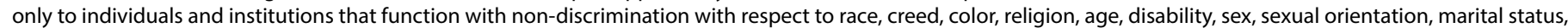

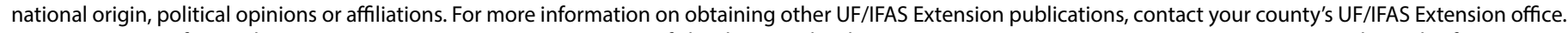
U.S. Department of Agriculture, UF/IFAS Extension Service, University of Florida, IFAS, Florida A \& M University Cooperative Extension Program, and Boards of County Commissioners Cooperating. Nick T. Place, dean for UF/IFAS Extension. 
- People who care about water issues but also have room for improvement in terms of their adoption of water conservation practices (also known as the water-considerate majority). This audience is often women and is interested in adopting new practices and participating in further educational outreach (Warner et al., 2016).

- Homeowners' associations and their residents

- Real estate agents

- New residents to the state of Florida

- Green industry professionals

- Focus content to actions and topics that the audiences need the most, are most interested in, and are most willing to learn about.

- Residential audiences have indicated they are most interested in water conservation topics that relate to residential landscape practices, such as irrigation timing and sprinkler system efficiency. Other water conservation topics of interest to the audiences are local water quality, cleanliness of large water bodies, and clean water for recreation (Warner et al., 2016; Warner et al., 2018).

- Residential audiences have demonstrated low selfefficacy when it comes to water quality conservation, smart-irrigation systems, and large-scale transitioning of landscapes (Warner et al., 2018). This means that they do not feel confident in their ability to accomplish or implement some of those practices, and therefore they are less likely to adopt them. If any of your communications target one of these three topics, ensure that you give clear instructions on how to accomplish these tasks and help raise your audience's comfort level with the practical application of these management practices.
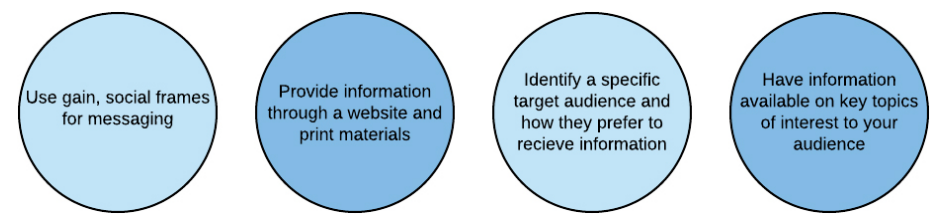

Figure 1. Water conservation communication best practices.

\section{How to Use This Information}

Extension professionals and other practitioners are encouraged to utilize this information in several ways:

\section{Review your existing communication materials and change} the framing if applicable. Is there a way to modify communications so they are presented using gain-frames and social expectations or personal values?
2. Ensure that your communication materials are being distributed through the most appropriate channels for your audience. Recent research shows that most Florida residents prefer to receive water conservation information either from websites or print materials. There will always be people who prefer to learn from you in person as well as those who will seek out material they can access on their own. Considering this, make sure you are providing information based on your audience's distinct needs. We also recommend that most workshops or outreach events should direct attendees to a website for more information. For example, at the end of a workshop, hand out a small flier with key takeaways, a website link, and a QR code to direct traffic to your website. This activity will also assist with analyzing the impact of extension activities. QR codes provide analytics indicating how many individuals utilized the code to access the website. Most websites provide basic analytics for free, including the number of visits, number of clicks, and number of unique visitors.

\section{Make sure you know who your target audience (clientele)} is, and how their needs might influence your communication strategies. Into what age group do they fall? How do they prefer to receive information from you? When is the best time to reach them? Knowing demographic information about your clientele and understanding their learning preferences can help you tailor your communication efforts to best reach your audiences. One way to identify the preferences and needs of your audience is by conducting a needs assessment. For more information about conducting and using a needs assessment, refer to the Conducting a Needs Assessment series (available at https://edis.ifas.ufl.edu/ topic_series_conducting_the_needs_assessment).

\section{Have information readily available on topics that are} of interest to your clientele. When you need to present information on topics that are of less interest to your clientele, consider linking the material with other topics. For water conservation topics that are more ambiguous or daunting, have materials that help break down that information into more understandable tasks that seem easily accomplished.

\section{Conclusion}

We note that there may be audience members who greatly need water conservation information but are not motivated to seek it out. While outside the scope of this document, it is important to consider how to best meet the needs of this important audience segment. For example, instead of directly receiving water conservation information, this 
audience may require assistance with other essential needs (such as housing or nutrition, etc.) before they can focus on water conservation, or they may require help recognizing the need to conserve water before they are ready or willing to access information from you.

This document has consolidated available information and research to provide tips on how to best connect and communicate with residential audiences about landscape water conservation practices. It has provided information on identifying preferred communication channels and described some key target audiences, along with guidelines for framing your messages and topics of interest to include. Future communication efforts should employ social and gain frames, convey easily adaptable and affordable actions, and ensure their information is being distributed either via websites or print materials.

\section{Acknowledgement}

This document was developed with support from the Florida Nursery, Growers and Landscape Association (FNGLA) Endowed Research Fund.

\section{References}

Lamm, A. J., Lundy, L. K., Warner, L., \& Lamm, K. W. (2016). Associating importance with behavior: Providing direction for water conservation communication. Journal of Applied Communications, 100(3), 44-56. Retrieved from http://newprairiepress.org/jac/vol100/iss3/6/

Richetin, J., Perugini, M., Mondani, D., \& Hurling, R. (2016). Conserving water while washing hands: The immediate and durable impacts of descriptive norms. Environment and Behavior, 48(2), 343-364. doi:10.1177/0013916514543683

Rumble, J. N., Lamm, A. J., Martin, E. T., \& Warner, L. A. (2017). Examining thought processes to understand the impact of water conservation messages on attitude. Journal of Agricultural Education, 58(3), 168-184. doi:10.5032/ jae.2017.03168

Warner, L. A., Lamm, A. J., \& Kumar Chaudhary, A. (2018). Florida residents' perceived role in protecting water quantity and quality through landscape practices. Landscape and Urban Planning, 171, 1-6. doi:10.1080/1533 015X.2017.1388199

Warner, L. A., Lamm, A. J., \& Rumble, J. N. (2018). Can videos play a role in good landscape management practices?
Applied Environmental Education \& Communication, 17(3), 187-197. doi:10.1080/1533015X.2017.1388199

Warner, L. A., Kumar Chaudhary, A., \& Lamm, A. J. (2016). Using importance-performance analysis to guide extension needs assessment. Journal of Extension, 54(6). Retrieved from https://joe.org/joe/2016december/a1.php

Warner, L. A., Kumar Chaudhary, A., Rumble, J. N., Lamm, A. J., \& Momol, E. (2017). Using audience segmentation to tailor residential irrigation water conservation programs. Journal of Agricultural Education, 58(1), 313-333. doi:10.5032/jae.2017.01313

Warner, L. A., Rumble, J. N., Martin, E., Lamm, A. J., \& Cantrell, R. A. (2015). The effect of strategic message selection on residents' intent to conserve water in the landscape. Journal of Agricultural Education, 56(4), 59-74. doi:10.5032/jae.2015.04059

Warner, L. A., Rumble, J. N., \& Rogers-Randolph, T. (2019). Integrating personal involvement, goal orientation, and characteristics of innovations to inform fertilizer best practices video communications. Journal of Agricultural Education, 60(3), 47-61. doi:10.5032/jae.2019.03047 